\title{
FOREIGN LEARNERS' PERCEPTION, SATISFACTION, AND LEARNING OUTCOME IN LEARNING INDONESIAN LANGUAGE
}

\author{
Imam Suyitno ${ }^{1 *}$, Kusubakti Andayani $^{1}$, Peni Dyah Anggari ${ }^{1}$, Taufiq Kurniawan ${ }^{1}$, \\ Heni Dwi Arista ${ }^{2}$ \\ ${ }^{1}$ Universitas Negeri Malang, Indonesia \\ ${ }^{2}$ Universitas Brawijaya, Indonesia \\ *e-mail: imam.suyitno.fs@um.ac.id
}

\begin{abstract}
Indonesian language learning institute for foreign learners emphasizes on increasing the experiences and skills of foreigners to speak Indonesian in the real context. One of the models used to achieve this is by optimizing the learning process. Therefore, this research studied the learning model and its impact on the perceptions, satisfaction, and outcomes using qualitative and quantitative approaches. The sample study consists of 21 foreign learners and 10 tutors. Data were obtained from the experientialtutorial learning, scores of perception, satisfaction, and outcomes through interviews, questionnaires, and tutor assessment on the speaking abilities recorded on document sheets. The study found that the experiential-tutorial learning was developed based on the learners' daily communication needs. The statistical analysis results showed that the average scores of their perception, satisfaction, and learning outcomes were in the high category. Therefore, foreign learners have a good perception and high learning satisfaction in conducting experiential-tutorial learning to increase their outcomes. These findings indicate that experiential-tutorial learning is an effective model for foreign language learners.
\end{abstract}

Keywords: experiential-tutorial learning, perception, satisfaction, learning outcome, learning Indonesian, foreign learners.

\section{PERSEPSI, KEPUASAN, DAN HASIL BELAJAR PELAJAR ASING DALAM PEMBELAJARAN BAHASA INDONESIA}

\begin{abstract}
Abstrak: Pembelajaran bahasa Indonesia untuk pelajar asing lebih menekankan pada peningkatan pengalaman dan keterampilan pelajar untuk berbicara bahasa Indonesia dalam konteks nyata. Optimalisasi praktik berbahasa menjadi salah satu model yang diterapkan dalam kegiatan pembelajaran. Dalam penelitian ini, model pembelajaran dan dampaknya terhadap persepsi, kepuasan, dan hasil belajar dikaji melalui pendekatan kualitatif dan kuantitatif. Subjek penelitian adalah 21 pelajar asing dan 10 tutor yang sedang menerapkan pembelajaran tutorial. Data penelitian adalah informasi tentang model implementasi pembelajaran eksperiential-tutorial dan skor tentang persepsi, kepuasan belajar, dan hasil belajar. Informasi tersebut dikumpulkan melalui wawancara dan analisis dokumen perencanaan pembelajaran dan data skor dikumpulkan dengan kuesioner dan penilaian tutor tentang kemampuan berbicara pelajar yang terekam dalam dokumen lembar penilaian. Temuan kajian menunjukkan bahwa model pembelajaran eksperientialtutorial dikembangkan berdasarkan analisis kebutuhan belajar pelajar asing dalam komunikasi sehari-hari. Hasil analisis statistik menunjukkan bahwa skor rata-rata persepsi, kepuasan, dan hasil belajar pelajar asing termasuk dalam kategori tinggi. Ini berarti bahwa pelajar asing memiliki persepsi yang baik dan kepuasan belajar yang tinggi dalam melakukan pembelajaran eksperiential-tutorial sehingga meningkatkan hasil belajar mereka. Temuan ini menyarankan bahwa pembelajaran eksperiential-tutorial adalah model pembelajaran yang efektif untuk diimplementasikan dalam pembelajaran bahasa untuk pelajar asing.
\end{abstract}

Kata Kunci: pembelajaran eksperiensial-tutorial, persepsi, kepuasan, hasil belajar, pembelajaran bahasa Indonesia, pelajar asing.

\section{INTRODUCTION}

Foreign learners are persons admitted in accredited institutions situated in countries other than their own, usually under special permits or visas, for the specific purpose of studying a particular course. In Indonesia, most 
foreign learners are adults and possess various self-factors, namely motivation, attitude, age, intelligence, aptitude, cognitive style, and personality, significantly influencing their learning process and outcome (Abante, Almendral, Manansala, \& Manibo, 2014). Therefore, lecturers need to consider these factors, as well as the requirements and learning styles of each learner when planning the curriculum(Knutson, 2003). Furthermore, during the language learning process, there is a need to emphasize the social aspects of communication, including considering the learners' psychological dimensions (Cook, 2017).

Preliminary studies discovered that these learners gained inconsistent experiences with their expectations because knowledge was mostly acquired from books. The learning activities are majorly focused on reading practices and answering the subsequent questions. However, the experiences acquired were not optimally applied in everyday conversation. Irrespective of the numerous language materials, they lacked the opportunity to practice using Indonesian in real communication. They mostly relied on reading comprehension, answering subsequent questions, using grammar, and writing assignments. Finally, they encountered numerous problems whenever they tried to converse with someone. Learning in a real environment tends to enhance students' positive attitudes, which impacts their communication skills (Siswanto, Karimullah, Prasetyawati, \& Nurhayati, 2019).

Foreign learners need to gain experiences, and this offers certain benefits when communicating with Indonesians. Conversely, there is a need to acquire knowledge directly from daily conversations with their friends. They also desire to gain cultural experiences, particularly those related to their day-to-day needs and activities. Therefore, they prefer learning from real communication and not from books. These learners also dislike explanations concerning language theory, rather they are interested in conversing and discussing real objects.

In addition, learners are expected to have functional learning experiences to improve their communication skills in daily conversations, both in academic and social contexts. It is also expected of them to acquire knowledge that automatically supports their communication skills and needs. According to Gusnawaty \&
Nurwati (2019), they prefer to obtain a real or functional learning experience applied in daily conversation. Foreign learners desire to gain language experience or knowledge regarding the Indonesian culture. They prefer a particular learning strategy that was expected to be adopted in the teaching-learning process. It also involves the need to deal directly with the learning objects, including communicating with Indonesians. They desire to be fluent in the use of Indonesian and possess significant cultural knowledge that aids in their communication needs. This condition illustrates that foreign learners tend to encounter several problems when learning languages. They have preferences, although the expected learning activities are irrelevant to their needs.

Therefore, experiential-tutorial learning was implemented for foreign learners to meet these requirements. The models were viewed as being relevant to their expectations, and this experiential-tutorial strategy focuses on communication. It provides opportunities for foreign learners to practice the target language, both maximally and naturally. This occurs because they are exposed to new objects and phenomena that stimulate and encourage them to learn. This stimulation further triggers them to use the language in the context of real communication. In this circumstance, they usually realize their assignments, determine their experiences, including directing their learning actions.

Experiential-tutorial learning considered the individual differences of foreign learners during the implementation of certain activities. This is also based on the characteristics and goals of the learners (Cook, 2017). However, by considering these requirements, learning activities became more meaningful to them because they acquired experiences according to their needs (Burbules, 2012). There is a need for these activities to be properly designed because it aids the learning process to be absolutely effective, efficient, productive, and interesting (Morrison, Ross, \& Kemp, 2004).

Based on the aforementioned description, this study is aimed to analyze (a) the implementation of experiential-tutorial learning and (c) its impact on learners' perception, satisfaction, and learning outcome. The findings are highly valuable because as an exploratory 
research, there is a need to implement the experiential-tutorial activities as a second language learning strategy. This program is also useful because it improves language learning plans and boosts the success of other activities. The findings were used as feedback by the instructors, tutors, and institutions. It is also useful for further studies intended to examine this topic, particularly as a second language learning strategy. Therefore, this research serves as a reference source in the development of a theoretical framework, data collection, and analysis.

\section{METHOD}

This study adopted a mixed procedure, namely, qualitative and quantitative approaches. The qualitative approach was used to describe the implementation of experiential-tutorial learning models, while the quantitative method was applied to examine its impact on the perceptions, satisfaction, and learning outcomes. The subject of this research involves 21 foreign learners - all of them were studying Indonesian - and 10 tutors that aided them in tutorial language learning activities. The total number and percentage of foreign learners and their countries of origin are shown in Table 1.

Table 1. The Country of Origin of Foreign Learners

\begin{tabular}{|c|c|c|}
\hline No. Country of Origin & Total & $\begin{array}{c}\text { Percentage } \\
(\%)\end{array}$ \\
\hline 1. Thailand & 4 & 19.05 \\
\hline 2. India & 1 & 4.76 \\
\hline 3. Vietnam & 1 & 4.76 \\
\hline 4. Cambodia & 1 & 4.76 \\
\hline 5. Ukraine & 1 & 4.76 \\
\hline 6. Madagascar & 1 & 4.76 \\
\hline 7. China & 4 & 19.05 \\
\hline 8. Egypt & 2 & 9.52 \\
\hline 9. South Korea & 5 & 23.81 \\
\hline 10. Papua New Guinea & 1 & 4.76 \\
\hline Sum & 21 & 100 \\
\hline
\end{tabular}

The information realized from this study consists of verbal and numerical data. Verbal data was centered on the implementation of experiential-tutorial learning for foreign learners. Subsequently, data were collected through interviews and document analysis of the learning plans. Numerical data were based on the scores of learners' perception, satisfaction, and learning outcomes. Conversely, these were obtained using questionnaires. Meanwhile, scores assigned to the learners' speaking abilities were collected using the tutors' assessment document sheet as shown in Appendix 5. The following indicators in the questionnaire were used to measure the learners' perception and satisfaction, (a) the significance of the learning targets, (b) the accuracy of the learning topics, (c) the scope of the cultural topics, and (d) the meaning of the learning activities (the grid for questionnaire development is shown in Appendix 1 and 2). Furthermore, before it was used for data collection, the questionnaire was validated by two psychology lecturers to determine the accuracy and appropriateness of the items, particularly with regards to the content of the statement. The following suggestions were made, namely (1) combining the contents of similar statement items, (2) changing the structure of statement items, and (3) including the statement items, which consists of the revised questionnaire used for data collection as shown in Appendix 3 and 4. This research categorized the learners' scores to determine their level of perception, satisfaction, and learning outcomes, based on the criteria.

The data analysis was carried out both qualitatively and quantitatively. Verbal data related to the implementation of experientialtutorial learning was evaluated qualitatively. This procedure consists of (a) reducing the data to determine the learners' needs during language learning, (b) classifying data to formulate learning goals and targets in accordance with experiential-tutorial strategies, (c) categorizing data to determine language and cultural learning materials, including activities for communicative purposes, and (d) interpreting data to construct the models of experiential-tutorial learning. Quantitatively, statistical calculations were carried out to analyze the scores of learners' perceptions, satisfaction, and speaking abilities. The procedures involved were (1) tabulating the scores, (2) calculating the average score, (3) calculating the standard deviation and variance, (4) presenting the results from the analysis, (5) interpreting the implication of experientialtutorial strategies on perception, satisfaction, learning outcomes, and (6) describing the results from the analysis. 


\section{FINDINGS AND DISCUSSION Findings}

\section{The Implementation of Experiential-Tutorial} Learning in Indonesian Learning

The implementation of the experientialtutorial learning is described based on (a) the learning targets, (b) the Indonesian learning materials, (c) the cultural learning materials, and (d) the learning strategies. These four aspects are shown in the Table 2.

The implementation of experientialtutorial learning was developed based on the learners' needs. The goals were determined in accordance with their expectations, which involves being fluent in real communication according to the context and topic of discussion. This learning strategy directly involved foreign learners in real communication for them to gain a more meaningful experience. Therefore, it was hoped that learners can speak Indonesian contextually and acquire new knowledge concerning the culture, including making their personal learning choices.

In carrying out experiential-tutorial learning, each learner was paired with a tutor that served as a learning partner. They guided, directed, and encourage learners to have the zeal and initiative to speak Indonesian during a conversation, and they were able to realize this by adopting various techniques. They played the role of motivators, facilitators, and reference models in language learning. The tutors' determination as learning partners was based on the following considerations, age, gender, hobbies of the learners, and the ability to speak Indonesian to them.

Table 2. The Aspects of Experiential-Tutorial Learning

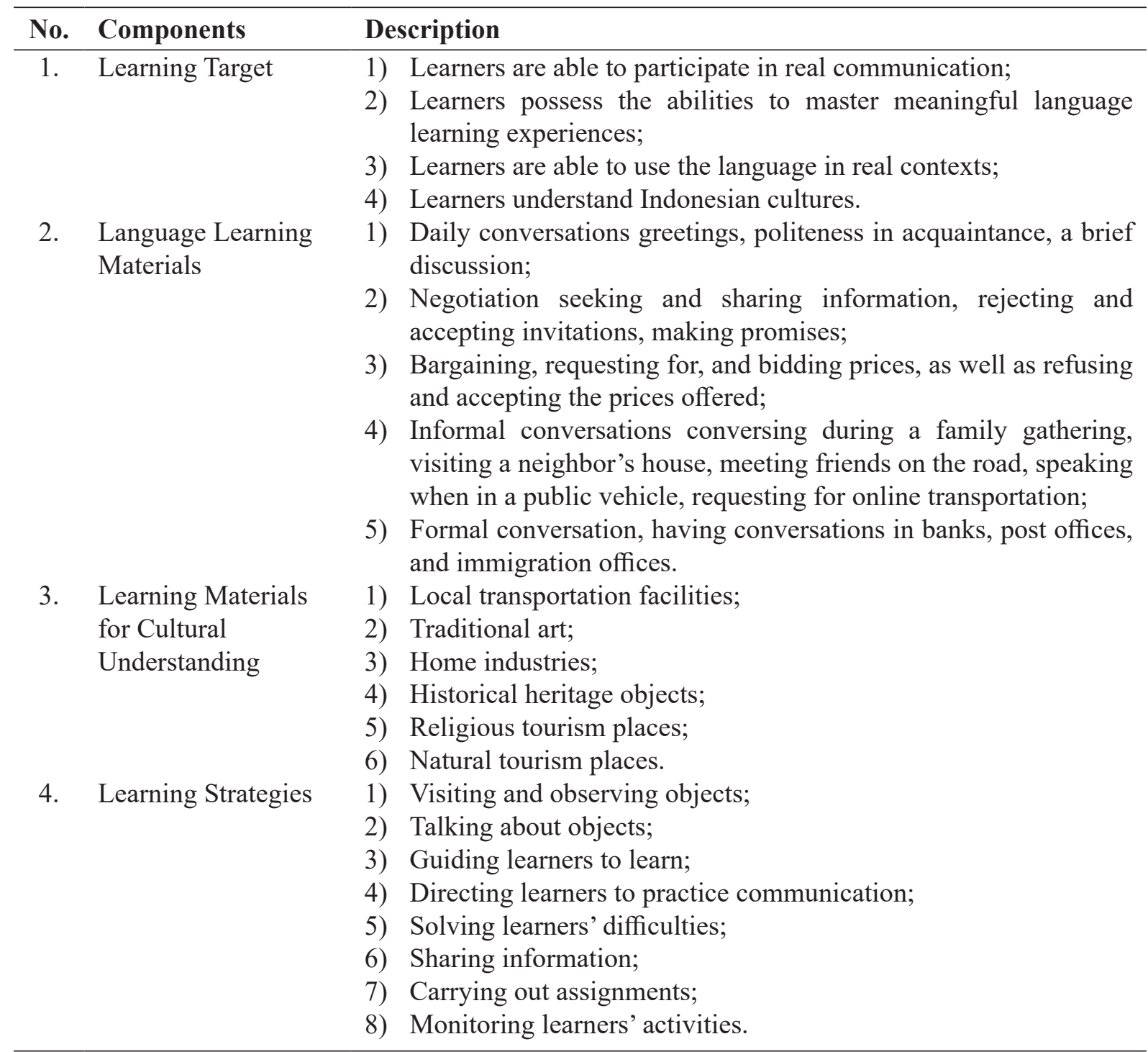


The Perception and Satisfaction of Foreign Learners in Carrying out Experiential-Tutorial Learning

The experiential-tutorial learning process's impact is measured based on the scores assigned to the learners' perceptions and satisfaction after completing the procedure. The overall scores obtained by each learner are shown in Appendix 6 . The categories and distribution of scores are shown in the Table $3,4,5,6,7$, and 8 .

Table 3. Learners' Perception of each Activity of Tutorial Aspect

\begin{tabular}{|c|c|c|c|c|}
\hline $\begin{array}{c}\text { Range of } \\
\text { No. } \\
\text { Score }(p)\end{array}$ & Category & $\begin{array}{l}\text { Items } \\
\text { Number }\end{array}$ & $\begin{array}{c}\text { Item } \\
\text { Frequency }\end{array}$ & $\begin{array}{l}\text { Percent- } \\
\text { age }\end{array}$ \\
\hline 1. $1<p \leq 2$ & Poor & 0 & 0 & 0 \\
\hline 2. $2<p \leq 3$ & Moderate & 0 & 0 & 0 \\
\hline 3. $3<p \leq 3.5$ & Good & $1,2,3,8,12$ & 5 & 35.71 \\
\hline 4. $3.5<p \leq 4$ & Very Well & $\begin{array}{l}4,5,6,7 \\
9,10,11 \\
13,14\end{array}$ & 9 & 64.29 \\
\hline
\end{tabular}

Most of the learning activities were carried out through the experimental-tutorial model, which was rated very well by foreign students. However, only a few activities were considered good by them.

Table 4. The Category of Learners' Perception in the Tutorial Activity

\begin{tabular}{cllcc}
\hline No. & $\begin{array}{l}\text { Range of } \\
\text { Score }(\boldsymbol{p})\end{array}$ & Category & Frequency & $\begin{array}{c}\text { Percent- } \\
\text { age }\end{array}$ \\
\hline 1. $1<p \leq 2$ & Poor & 0 & 0 \\
2. $2<p \leq 3$ & Moderate & 0 & 0 \\
3. $3<p \leq 3.5$ & Good & 6 & 28.57 \\
4. $3.5<p \leq 4$ & Very Well & 15 & 71.43 \\
\hline Mean $=3.6124$, Std. Deviation $=.1977, N=21$ \\
\hline
\end{tabular}

Almost all foreign learners have very well perceptions about the implementation of experiential-tutorial models in learning Indonesian. This showed that it was suitable for their learning needs.
Table 5. Foreign Learners' Perception of the Implementation of ExperientialTutorial Learning

\begin{tabular}{lrr}
\hline & & Perception \\
\hline$N$ & Valid & 21 \\
& Missing & 0 \\
Mean & 90.306 \\
Std. Error of Mean & 1.078 \\
Median & 92.860 \\
Std. Deviation & 4.941 \\
Variance & 24.417 \\
Minimum & 80.360 \\
Maximum & 98.210 \\
\hline
\end{tabular}

The distribution of scores was extremely high, although the difference among them was insignificant. These results showed that all foreign learners had a very good perception of the experiential-tutorial learning model. These findings proved that this process was carried out appropriately. It simply means that the learning targets were suitable and relevant to the learners' needs. In addition, they were able to realize their goals through experiential-tutorial activities. The topic learnt was also considered relevant to their needs in daily communication. Conversely, this strategy helped learners to understand the cultural topic required in day-today conversation. The learning activities carried out in the experiential tutorial was also relevant to the learners' preferences.

Table 6. Learners' Satisfaction for each Activity of Tutorial Aspect

\begin{tabular}{|c|c|c|c|c|c|}
\hline & $\begin{array}{l}\text { Range of } \\
\text { Score }(s)\end{array}$ & Category & $\begin{array}{l}\text { Items } \\
\text { Number }\end{array}$ & $\begin{array}{c}\text { Item } \\
\text { Frequency }\end{array}$ & $\begin{array}{c}\text { Percent- } \\
\text { age }\end{array}$ \\
\hline 1. & $2<s \leq 3$ & $\begin{array}{l}\text { Low } \\
\text { satisfied }\end{array}$ & 0 & 0 & 0 \\
\hline 2. & $3<s \leq 3.5$ & Satisfied & $2,5,9,10$ & 4 & 40 \\
\hline 3. & $3.5<s \leq 4$ & $\begin{array}{l}\text { High } \\
\text { Satisfied }\end{array}$ & $\begin{array}{l}1,3,4,6 \\
7,8\end{array}$ & 6 & 60 \\
\hline
\end{tabular}

Foreign students felt very satisfied with a variety of language learning activities realized through experiential-tutorial models. Some of the activities assessed by students were not optimal, and it needed to be improved. 
Table 7. The Category of Learners' Satisfaction in Receiving Tutorial Services

\begin{tabular}{cllcc}
\hline No. & $\begin{array}{l}\text { Range of } \\
\text { Score }(s)\end{array}$ & Category & Frequency & $\begin{array}{c}\text { Percent-- } \\
\text { age }\end{array}$ \\
\hline 1. & $1<s \leq 3$ & Low satisfied & 0 & 0 \\
2. & $3<s \leq 3.5$ & Satisfied & 6 & 28.57 \\
3. & $3.5<s \leq 4$ & High Satisfied & 15 & 71.43 \\
\hline Mean $=3.5857$, Standard Deviation $=.24957, N=21$ \\
\hline
\end{tabular}

Almost all foreign learners were categorized as having very high satisfaction regarding the application of the experimental-tutorial learning model. This showed that learners acquired experiences according to their needs.

Table 8. Foreign Learners' Satisfaction in the implementation of ExperientialTutorial Learning

\begin{tabular}{lrr}
\hline & & Satisfication \\
\hline $\mathrm{N}$ & Valid & 21 \\
& Missing & 0 \\
Mean & 89.643 \\
Std. Error of Mean & 1.362 \\
Median & 90.000 \\
Std. Deviation & 6.239 \\
Variance & 38.929 \\
Minimum & 77.500 \\
Maximum & 100.000 \\
\hline
\end{tabular}

The distribution of scores was extremely high. However, the differences among them were quite insignificant. These results showed that all foreign learners had a very good perception of the experiential-tutorial learning model. Generally, they were categorized as being very satisfied with this procedure, although some of them consider it to be ordinary. They also felt happy because they acquired valuable experiences from these learning activities. They had opportunities to practice the ways and manners of communication. They had efficient tutors as learning partners that always helped them to overcome their difficulties. Therefore, the experiential-tutorial model was implemented for foreign learners because the learning activities meet their preferences.

\section{The Learning Outcomes of Foreign Learners in Learning Indonesian}

The experiential-tutorial impact on learning outcomes is measured based on the scores assigned to the learners' speaking ability after completing the learning process. The overall scores of each learner are shown in Appendix 6. The categories and distribution of scores are shown in the Table 9 and 10.

Table 9. The Ability of Learners to Speaking Indonesian

\begin{tabular}{llcc}
\hline $\begin{array}{l}\text { Nange of Score } \\
(\boldsymbol{a})\end{array}$ & Category & Frequency & Percentage \\
\hline 1. $a<60$ & Poor & 0 & 0 \\
2. $60<a \leq 70$ & Average & 6 & 28.57 \\
3. $70<a \leq 80$ & Good & 13 & 61.91 \\
4. $a>80$ & Excellent & 2 & 9.52 \\
\hline
\end{tabular}

Mean $=70.2381$, Standard Deviation $=.69640, N=21$

Learning outcomes achieved by learners in learning Indonesian by adopting the experimental-tutorial model varied (average, good, and excellent). Generally, their learning outcomes were in a good category.

Table 10. Speaking Ability Achieved by Foreign Learners through Experiential-Tutorial Learning

\begin{tabular}{lrr}
\hline & \multicolumn{1}{r}{ Learning Outcome } \\
\hline$N$ & Valid & 21 \\
& Missing & 0 \\
Mean & & 72.381 \\
Std. Error of Mean & 1.520 \\
Median & 75.000 \\
Std. Deviation & 6.964 \\
Variance & 48.498 \\
Minimum & 60.000 \\
Maximum & 86.000 \\
\hline
\end{tabular}

Based on the average, minimum, and maximum scores, it was reported that experientialtutorial learning aided in improving the learners' learning outcomes, particularly in verbal communication. Students were able to master the vocabulary and speak fluently. Although some weaknesses were discovered in their inability to pronounce and use certain grammatical terms 
appropriately. Diverse language characteristics and cultural backgrounds caused the difference in the ability to speak properly among them.

\section{Discussion}

\section{Experiential-Tutorial Learning in Indonesian Learning for Foreign Learners}

The findings showed that experientialtutorial learning was developed based on the learning needs of foreign learners. In addition, the learning targets, materials, strategies, and activities were also determined based on their requirements. This was intended to meet their expectations in the learning process. This was considered useful because learners' needs and expectations are underlying characteristics of an individual, which is causally related to effective criterion-referenced or superior performance in learning activities (Roberts, 2016). Zhang, Han, Zhao, \& Meng (2018) reported that understanding these needs is the starting point in carrying out the teaching-learning process because all components of the system are designed based on the learner's competence in order to ensure that it is run effectively.

Subsequently, experiential-tutorial learning was carried out by focussing on individual learning activities, particularly in the cultural context. In the learning contexts, the tutors' role is to guide, direct, and encourage them to communicate in Indonesian. Learners were actively involved in learning and possessing the initiative to acquire experiences. They were directed by the tutors to reflect on their needs. At the beginning of the process, they also help them study and give feedback at the end of the learning session (Moon, 2009).

The goal of experiential-tutorial learning was to motivate foreign learners to be fluent or competent in real communication. They are expected to be skilled in order to be able to communicate with native speakers daily. In a working environment, this language proficiency plays a significant role, namely, it aids an individual to secure a job as well as reach the desired position. Language proficiency offers exceptional advantages for foreign learners in terms of their abilities to either work abroad or in their own country (Rajprasit \& Hemchua, 2015). Good language skills are required for successful social interaction (Shrestha, Pahari, \& Awasthi, 2017; Louhiala-Salminen \& Kankaanranta,
2011). The experiential-tutorial strategies for language learning also aided in improving the communicative competence of language learners (Bloom \& Gascoigne, 2017).

The materials used during the experientialtutorial relied on language skills. This is due to the fact that it helps individuals to be able to express their thoughts and ideas and also meet their various needs. The fundamental expression of language helps people communicate their observations, thoughts, and feelings (McKay, Davis, \& Fanning, 2009). Therefore, various language functions need to be taught because different vocabularies and expressions are included in the communication context (Armstrong \& Ferguson, 2010). They also need to be trained to adjust their language style during the conversation. They need to determine their choice of language when speaking either formally or informally (Eggins \& Slade, 2005). Ahlsén (2005) reported that the various aspects and factors involved in functional communication events play an important role in influencing an individual's choice of language.

The topics based on cultural learning are an important aspect of language learning for foreign learners. Cultural objects aids in ascertaining that the language learned was relevant to the actual communication context (Bax, 2003). However, learners need not only learn the language, they also need to embrace the culture. Cultural learning aids foreign learners to gain useful knowledge that enhances their mastery of the language (van Schaik \& Burkart, 2011). Pooley \& O'Connor (2000) reported that it is also aimed to trigger learners' awareness of the culture.

Experiential-tutorial learning offers learners the widest opportunity to master the language. It also provides the necessary exposure, which maximizes input in language acquisition. This is consistent with the research carried out by Taguchi (2018), which stated that learning a language is effectively carried out in the social context because it aids learners to socialize with their environment. This offers broad opportunities to its practice in the realworld (Benade, 2015). The selection of objects based on the learners' needs causes them to be eager to learn because they feel safe and avoid carrying out certain activities (Osborne, 2016). It made them active during decision-making 
and positively correlates with increased intrinsic motivation of learning, overall achievement, and creativity, including higher-order thinking (Toshalis \& Nakkula, 2012). These activities helped learners to gain meaningful experiences according to their learning needs (Burbules, 2012).

Based on the description above, it was reported that experiential-tutorial learning motivated learners to study and practice the language's optimal use. This learning technique is also helpful based on an intensive mentoring process. Experiential-tutorial learning is a model designed to stimulate students to learn through the following processes, offering guidance, assistance, direction, and motivation in order to produce efficient and effective learners (Klein, 2009). Learning is properly carried out, supposing there is a two-way interaction between the tutors and foreign learners (Sani, 2013).

In addition, during the implementation of experiential-tutorial learning, it was deemed necessary to understand students' needs. Information concerning it is obtained through needs analysis (Hardini, Setyarini, \& Harto, 2019). Lam (2015) reported that understanding the information on learners' needs as necessary. Need analysis is a systematic process of gathering and using the information to improve learning, including developing learners' competencies (Palomba \& Banta, 1999; Rostami \& Zafarghandi, 2014). It was the initial stage in designing learning programs, materials, and activities (Ulum, 2016). Unal \& Ilhan (2017) researched learning a foreign language in higher education by stating that teaching needs to be more practical. All four skills, namely elective courses, practice and communication, and revisions in the teacher training system, are considered motivating and encouraging factors for learners to meet their various needs.

\section{The Impact of Experiential-Tutorial Learning on Learners' Perception, Satisfaction, and Learning Outcomes}

The impacts of experiential-tutorial learning are evident in the results of the data analysis. In accordance with Table 4, it was determined that generally, learners have very good perceptions of language learning through experiential-tutorial strategies. This finding showed that through this process, foreign learners gained experiences related to their initial abilities. Learners obtained the activities they desired during the tutorial process. Furthermore, tutors provided useful guidance and always motivated them to be enthusiastic about learning. They also applied the learning principles and properly designed these activities in such a manner that the learners easily understood them. Tutors are always friendly and tend to create a learning model for learners.

The high perception of learners showed that experiential-tutorial learning was used to answer the learners' internal demands. Rostami \& Zafarghandi (2014) stated that understanding the learning needs as well as assessing them are important factors that have to be considered when carrying out learning procedure. This involves the process of learners' acceptance and appreciation of the learning situation based on their expectations. The perception became meaningful in accordance with the stimulus it received through the process of recognition, understanding, and reasoning. In the learning process, creating situations to arouse learners' good perceptions was an important aspect of designing these activities. This needs to be carried out because a good perception rapidly, specifically, and efficiently strengthens the learners' sensory nerves (Carbon, 2014).

In Table 7, the findings showed that learners' satisfaction towards the implementation of experiential-tutorial learning is in the high category. The foreign learners felt very satisfied because they effectively participated in carrying out this procedure. They also appreciated the tutors' attitude in carrying out tutorial activities. The high learners' satisfaction has an impact on the processes that occurred during the teachinglearning session (Wu, Hsieh, \& Lu, 2015). This shows that experiential-tutorials learning renders services that meet the expectations of foreign learners. They gained relevant experiences in carrying out experiential-tutorial activities. These findings are consistent with the study carried out by Oliver (1999), which reported that learning satisfaction tends to occur because the expectations of learners align with the learning services rendered (Oliver, 1999).

The high satisfaction of the learners was due to effective interaction during learning. The services rendered through experientialtutorial learning tend to trigger foreign 
learners' satisfaction in carrying out learning activities. The quality of service, teaching, and involvement in the learning environment is closely related to the learners' satisfaction and learning success (Ellis, Goodyear, Calvo, \& Prosser, 2008; Green, Hood, \& Neumann, 2015; Knight, 2002). The previous studies discovered that the quality of teaching, which includes its implementation, facilities, learning process, service, and curriculum are important factors that ensure learning satisfaction, maintains learners' loyalty, as well as increasing learning outcomes (Hennig-Thurau, Langer, \& Hansen, 2016; Kekkonen-Moneta \& Moneta, 2002).

Foreign learners were satisfied with experiential-tutorial learning because they had the opportunity to communicate with the tutors directly. The learners positively viewed this activity because of the required experience (Herdlein \& Zurner, 2015). Based on the results of this study, it was reported that language learning realized through experiential-tutorial activities fulfills foreign learners' needs. Their satisfaction is one of the basic requirements for achieving success during the implementation of learning programs (Naaj, Nachouki, \& Ankit, 2012). Therefore, the reliability of tutors is based on their interactions during the learning process, particularly the availability and the response time, which were highly correlated to the learners' satisfaction and learning outcomes (DeBourgh, 1999).

Table 9 showed that foreign learners are bound to obtained good speaking skills through experiential-tutorial learning. The findings showed that foreign learners acquired numerous experiences in the use of vocabulary and grammar. They were also exposed to multiple opportunities that entailed practicing communication methods, which influenced their speaking and pronunciation. The high level of learners' satisfaction determined their achievement. The level of learner satisfaction determines their motivation to obtain more knowledge or skills (Razinkina, Pankova, Trostinskaya, Pozdeeva, Evseeva, \& Tanova, 2018). This positively triggers learners' attitudes and supports successful learning procedures.

Experiential-tutorial activities train learners to be able to learn a language independently. In these activities, tutors are assigned to guide and resolve the learning difficulties of the learners. The tutorial activity triggers learners' sensitivity when they encounter problems during the on-going tutorial activities (Wlodkowski \& Jaynes, 1991). Although these activities entail that learners study individually, thereby specifically resolving any problem encountered. Furthermore, the speed of learning needs to be adjusted according to their abilities without being influenced by others. Foreign learners are widely exposed to opportunities to practice the language naturally (Becker, Matsugu, \& Al-Surmi, 2017).

In the experiential-tutorial activities, tutors are assigned the following tasks (a) guide and trigger the enthusiasm of learners, (b) provide challenges that motivate learners to improve their performance in these activities, and (c) help learners when they encounter language problems. Subsequently, during learning, the target of tutors is to measure the effectiveness of the learning. Constantly, they pay attention to the language development of the learner. The effectiveness of learning activities in tutorial interactions had a positive impact on learners' abilities (McFarlane, 2016).

\section{CONCLUSION}

Experiential-tutorial learning was one of the models adopted for learning a language by foreign learners. This learning model had a positive impact on learners' perceptions and satisfaction, thereby improving their learning outcomes. In addition, learners gained experiences that were relevant to their preferences and expectations. These findings were useful to the staff, instructors, and tutors for developing language learning plans. It also serves as a reference in developing the theoretical framework and the method of analysis.

\section{ACKNOWLEDGMENT}

The authors are grateful to the Indonesian language learning institutions for foreign students and tutors that helped conduct this research.

\section{REFERENCES}

Abante, M. E. R., Almendral, B. C., Manansala, J. E., \& Manibo, J. (2014). Learning Styles and Factors Affecting the Learning of General Engineering Students. International Journal of Academic 
Research in Progressive Education and Development, 3(1), 16-27. https://doi. org/10.6007/IJARPED/v3-i1/500.

Ahlsén, E. (2005). Argumentation with restricted linguistic ability: Performing a role play with aphasia or in a second language. Clinical Linguistics \& Phonetics, 19(5), 433-451. https://doi. org/10.1080/02699200400027205.

Armstrong, E., \& Ferguson, A. (2010). Language, meaning, context, and functional communication. Aphasiology, 24(4), 480-496. https://doi. org/10.1080/02687030902775157.

Bax, S. (2003). The end of CLT: A context approach to language teaching. ELT Journal, 57(3), 278-287. https://doi. org/10.1093/elt/57.3.278.

Becker, A., Matsugu, S., \& Al-Surmi, M. (2017). Balancing practicality and construct representativeness for IEP speaking tests. Asian-Pacific Journal of Second and Foreign Language Education, 2(18), 1-16. https://doi.org/10.1186/s40862017-0041-z.

Benade, L. (2015). Teaching as inquiry: Wellintentioned, but fundamentally flawed. New Zealand Journal of Educational Studies, 50(1), 107-120. https://doi. org/10.1007/s40841-015-0005-0.

Bloom, M., \& Gascoigne, C. (2017). Creating experiential learning opportunities for language learners: Acting locally while thinking globally. England: Multilingual Matters.

Burbules, N. C. (2012). Ubiquitous learning and the future of teaching. Encounters in Theory and History of Education, 13, 3-14. https://doi.org/10.24908/eoe-eserse.v13i0.4472.

Carbon, C.-C. (2014). Understanding human perception by human-made illusions. Frontiers in Human Neuroscience, 8(566). $\quad \underline{\text { https://doi.org/10.3389/ }}$ fnhum.2014.00566.
Cook, V. (2017). Second language learning and language teaching $\left(5^{\text {th }}\right.$ ed). New York, NY: Routledge.

DeBourgh, G. A. (1999). Technology is the tool, teaching is the task: Student satisfaction in distance learning. In J. Price, J. Willis, D. Willis, M. Jost \& S. Boger-Mehall (Eds.), Proceedings of SITE 1999-Society for Information Technology \& Teacher Education International Conference. Waynesville, NC USA: Association for the Advancement of Computing in Education (AACE), (pp. 131-137). https://www. learntechlib.org/primary/p/7521/.

Eggins, S., \& Slade, D. (2005). Analyzing casual conversation (New edition). United Kingdom: Equinox Publishing Limited.

Ellis, R. A., Goodyear, P., Calvo, R. A., \& Prosser, M. (2008). Engineering students' conceptions of and approaches to learning through discussions in face-to-face and online contexts. Learning and Instruction, 18(3), 267-282. https://doi.org/10.1016/j. learninstruc.2007.06.001.

Green, H. J., Hood, M., \& Neumann, D. L. (2015). Predictors of student satisfaction with university psychology courses: A review. Psychology Learning \& Teaching, 14(2), 131-146. https://doi. org/10.1177/1475725715590959.

Gusnawaty, G., \& Nurwati, A. (2019). A learning model of bahasa Indonesia as a foreign language based on local intercultural politeness. Cakrawala Pendidikan, 38(1), 141-155. https://doi.org/10.21831/ cp.v38i1.23164.

Hardini, T. I., Setyarini, S., \& Harto, S. (2019). Indonesian language assistant program in Australian schools: Recruitment and selection process. Cakrawala Pendidikan, 38(2), 330-342. https://doi.org/10.21831/ cp.v38i2.25083.

Hennig-Thurau, T., Langer, M. F., \& Hansen, U. (2016). Modeling and managing student loyalty: An approach based on the concept of relationship quality. Journal of Service Research, 3(4), 331-344. https://doi. 
org/10.1177/109467050134006.

Herdlein, R., \& Zurner, E. (2015). Student satisfaction, needs, and learning outcomes: A case study approach at a European University. SAGE Open, 5(2), 1-10.https:// doi.org/10.1177/2158244015580373.

Kekkonen-Moneta, S., \& Moneta, G. B. (2002). E-learning in Hong Kong: Comparing learning outcomes in online multimedia and lecture versions of an introductory computing course. British Journal of Educational Technology, 33(4), 423-433. https://doi.org/10.1111/1467-8535.00279.

Klein, W. A. (2009). Pendekatan baru strategi belajar mengajar berdasarkan CBSA (cet. 5). [A new approach to teaching and learning strategies based on CBSA]. Bandung: Sinar Baru Algensindo.

Knight, P. T. (2002). Summative assessment in higher education: Practices in disarray. Studies in Higher Education, 27(3), 275-286. https://doi. org/10.1080/03075070220000662.

Knutson, S. (2003). Experiential learning in second-language classrooms. TESL Canada Journal, 20(2), 52-64. https:// doi.org/10.18806/tesl.v20i2.948.

Lam, R. (2015). Language assessment training in Hong Kong: Implications for language assessment literacy. Language Testing, 32(2), 169-197. https://doi. org/10.1177/0265532214554321.

Louhiala-Salminen, L., \& Kankaanranta, A. (2011). Professional communication in a global business context: The notion of global communicative competence. IEEE Transactions on Professional Communication, 54(3), 244-262. https:// doi.org/10.1109/TPC.2011.2161844.

McFarlane, K. J. (2016). Tutoring the tutors: Supporting effective personal tutoring. Active Learning in Higher Education, 17(1), 77-88. https://doi. org/10.1177/1469787415616720.

McKay, M., Davis, M., \& Fanning, P. (2009).
Messages: The communication skills book. Oakland, CA: New Harbinger Publications.

Moon, J. A. (2009). A handbook of reflective and experiential learning: Theory and practice. New York, NY: Routledge.

Morrison, G. R., Ross, S. M., \& Kemp, J. E. (2004). Designing effective instruction $\left(4^{\text {th }}\right.$ ed). Boulevard: Wiley Publishing Inc.

Naaj, M. A., Nachouki, M., \& Ankit, A. (2012). Evaluating student satisfaction with blended learning in a gender-segregated environment. Journal of Information Technology Education: Research, 11, 185-200. https://doi.org/10.28945/1692.

Oliver, R. L. (1999). Whence consumer loyalty? Journal of Marketing, 63(4_suppl1), 33-44. https://doi. org/10.1177/00222429990634s105.

Osborne, M. (2016). Innovative learning environments. CORE Education White Paper.

Palomba, C.A., \& Banta, T. W.(1999).Assessment essentials: Planning, implementing and improving assessment in higher education $\left(1^{\text {st }}\right.$ ed). San Francisco, CA: Jossey-Bass Publishers.

Pooley, J. A., \& O'Connor, M. (2000). Environmental education and attitudes: Emotions and beliefs are what is needed. Environment and Behavior, 32(5), 711-723. https://doi. org/10.1177/0013916500325007.

Rajprasit, K., \& Hemchua, S. (2015). The English language \& communication in the international workplace: An examination of thai computer engineering professionals. 3L: Language, Linguistics, Literature, 21(3), 109-124. http:// ejournals.ukm.my/31/article/view/9222.

Razinkina, E., Pankova, L., Trostinskaya, I., Pozdeeva, E., Evseeva, L., \& Tanova, A. (2018). Student satisfaction as an element of education quality monitoring in innovative higher education institution. 
E3S Web of Conferences, 33, 03043.https:// doi.org/10.1051/e3sconf/20183303043.

Roberts, J. (2016). Language teacher education. London: Routledge.

Rostami, F., \& Zafarghandi, A. M. (2014). EAP needs analysis in Iran: The case of university students in Chemistry Department. Journal of Language Teaching and Research, 5(4), 924-934. https://doi.org/10.4304/jltr.5.4.924-934.

Sani, R. A. (2013). Inovasi pembelajaran. [Learning innovation]. Jakarta: Bumi Aksara.

Shrestha, R. N., Pahari, B. R., \& Awasthi, J. R. (2017). Importance of English in engineering for professional communication: A study in the Nepalese context. Journal of the Institute of Engineering, 12(1), 222-227. https://doi. org/10.3126/jie.v12i1.16906.

Siswanto, S., Karimullah, K., Prasetyawati, R., \& Nurhayati, N. (2019). Environmental cultured education and its implication on the student's competencies in an Adiwiyata school. Cakrawala Pendidikan, 38(3), 552-564. https://doi.org/10.21831/ cp.v38i3.23154.

Taguchi, N. (2018). Contexts and pragmatics learning: Problems and opportunities of the study abroad research. Language Teaching, 51(1), 124-137. https://doi. org/10.1017/S0261444815000440.

Toshalis, E., \& Nakkula, M. J. (2012). Motivation, engagement, and student voice. Job for the Future. https://www.
jff.org/documents/2047/Motivation Engagement_Student Voice 0.pdf.

Ulum, Ö. G. (2015). A needs analysis study for preparatory class ELT students. European Journal of English Language Teaching, l(1), 14-29. https://doi.org/10.5281/ zenodo.51774.

Unal, M., \& Ilhan, E. (2017). A case study on the problems and suggestions in foreign language teaching and learning at higher education. Journal of Education and Training Studies, 5(6), 64-72. https://doi. org/10.11114/jets.v5i6.2302.

van Schaik, C. P., \& Burkart, J. M. (2011). Social learning and evolution: The cultural intelligence hypothesis. Philosophical Transactions of the Royal Society B, 366(1567), 1008-1016. https://doi. org/10.1098/rstb.2010.0304.

Wlodkowski, R. J., \& Jaynes, J. H. (1991). Eager to learn: Helping children become motivated and love learning. San Francisco, CA: Jossey-Bass Publishers.

Wu, Y.-C., Hsieh, L.-F., \& Lu, J.-J. (2015). What's the relationship between learning satisfaction and continuing learning intention? Procedia-SocialandBehavioral Sciences, 191, 2849-2854. https://doi. org/10.1016/j.sbspro.2015.04.148.

Zhang, D., Han, J., Zhao, L., \& Meng, D. (2019). Leveraging prior-knowledge for weakly supervised object detection under a collaborative self-paced curriculum learning framework. International Journal of Computer Vision, 127, 363-38. https:// doi.org/10.1007/s11263-018-1112-4. 


\section{APPENDIX}

Appendix 1. Questionnaire Grid of Learners' Perceptual

\begin{tabular}{cllc}
\hline No. & Aspects & Indicators & Statement Items Number \\
\hline 1. & The learning & Reflect communicative goals & 1 \\
& targets & Aligned with the language learning objectives & 2 \\
& & Relevant to the learning needs & 3 \\
& & Can be achieved through tutorial activities & 4 \\
2. & The language & Relevant to the learning target & 5 \\
& learning & Used in daily communication & 6 \\
& topics, & Important for daily conversation & 7 \\
& & Can be learned through real contexts & 8 \\
3. & The cultural & Relevant to the learning target & 9 \\
& topics & Needed in daily communication & 10 \\
& & Important for communication & 11 \\
& & Can be obtained through real contexts & 12 \\
4. The learning & Relevant to the learning target & 13 \\
& activities & Relevant to learner preferences & 14 \\
\hline
\end{tabular}

Appendix 2. Questionnaire Grid of Learners' Satisfaction

\begin{tabular}{|c|c|c|c|}
\hline No. & Aspects & Indicators & Statement Items Number \\
\hline \multirow[t]{2}{*}{1.} & \multirow{2}{*}{$\begin{array}{l}\text { The learning } \\
\text { convenience }\end{array}$} & Feel comfortable in learning activities & 1 \\
\hline & & Feel happy with the topic of learning & 8 \\
\hline \multirow[t]{2}{*}{2.} & \multirow{2}{*}{$\begin{array}{l}\text { The functioning } \\
\text { of learning } \\
\text { outcomes }\end{array}$} & Gets valuable experience in learning & 2 \\
\hline & & $\begin{array}{l}\text { Gets language material that meets he/she } \\
\text { needs }\end{array}$ & 5 \\
\hline \multirow[t]{3}{*}{3.} & \multirow{3}{*}{$\begin{array}{l}\text { The learning } \\
\text { services }\end{array}$} & Ease in overcoming learning difficulties & 4 \\
\hline & & Can choose study material as needed & 10 \\
\hline & & Gets enough tutoring & 7 \\
\hline \multirow[t]{3}{*}{4.} & \multirow[t]{3}{*}{$\begin{array}{l}\text { The learning } \\
\text { activities }\end{array}$} & $\begin{array}{l}\text { Always guided to communicate naturally } \\
\text { with the community }\end{array}$ & 9 \\
\hline & & Motivated in learning activities & 6 \\
\hline & & $\begin{array}{l}\text { Enough opportunities to practice } \\
\text { communication }\end{array}$ & 3 \\
\hline
\end{tabular}

\section{Appendix 3. The Questionnaire of Learners' Perceptual}

\begin{tabular}{llll}
\hline No. & Statements & Scores \\
\cline { 2 - 3 } & & $\mathbf{2}$ & $\mathbf{3}$ \\
\hline 1. & These learning targets reflect communicative goals & \\
2. & The learning targets are aligned with the language learning objectives & \\
3. & The learning target is relevant to the learning needs & \\
4. & The learning target can be achieved through tutorial activities \\
5. & The learning topic is relevant to the learning target \\
6. & The learning topic is needed in daily communication \\
7. & The learning topic is important for daily conversation \\
8. & These learning topics can be learned through real contexts \\
9. & The cultural topic is relevant to the learning target \\
10. & The cultural topic is needed in daily communication \\
11. & These cultural topics are important for communication \\
12. & These cultural topics can be obtained through real contexts \\
13. & These learning activities are relevant to the learning target \\
14. & Learning activities are relevant to learner preferences & \\
\end{tabular}


Appendix 4. The Questionnaire of Learners' Satisfaction

\begin{tabular}{clr}
\hline No. & Statements & \multicolumn{2}{c}{ Scores } \\
\cline { 2 - 3 } & $\mathbf{2}$ & $\mathbf{3}$ \\
\hline 1. & The learner feel comfortable in learning activities & \\
2. & The learner gets valuable experience in learning & \\
3. & The learner get enough opportunities to practice communication \\
4. & The learner gets ease in overcoming learning difficulties \\
5. & The learner gets language material that meets he/she needs \\
6. & The learner is motivated in learning activities \\
7. & The learner gets enough tutoring \\
8. & The learner feel happy with the topic of learning \\
9. & The learner is always guided to communicate naturally with the community \\
10. & The learner can choose study material as needed & \\
\hline
\end{tabular}

Appendix 5. The Assessment Sheets for Scoring Learners' Speaking Abilities

\begin{tabular}{llllll}
\hline \multirow{2}{*}{ No. } & Statements & \multicolumn{3}{c}{ Scores } \\
\cline { 2 - 5 } & $\mathbf{1}$ & $\mathbf{2}$ & $\mathbf{3}$ \\
\hline 1. & Fluency of speech & & & \\
2. & Pronunciation of words & & & \\
3. & Variance of vocabulary & & & \\
4. & Accuracy of grammar & &
\end{tabular}

Note for scoring:

1. Fluency of speech: (1) Talks always stop and disjointed, (2) The conversation is very slow and not steady except for short sentences, (3) Talks often doubt, sentences are not sticky, (4) The conversation is smooth and wide but occasionally lacking.

2. Pronunciation of words: (1) Speech is not understood, (2) Big mistakes and strong accents that make understanding difficult, (3) incorrect pronunciation but did not cause misunderstanding, (4) Pronunciation approaches standard speech

3. The variance of vocabulary: (1) Mastery of vocabulary is very limited to basic personal needs, (2) The choice of vocabulary is often incorrect and the limitations of its use hamper the smooth communication in social and professional, (3) The use of technical vocabulary is appropriate in certain talks, but excessive use of general vocabulary, (4) Use of technical vocabulary is broader and more accurate.

4. Accuracy of grammar: (1) There are errors in the use of fixed patterns that always interfere with communication, (2) Often occurring in a certain pattern because it is less careful that can interfere with communication, (3) Sometimes there are errors in the use of certain patterns, but does not interfere with communication, (4) there are errors, but not significant use.

\section{Appendix 6. Recapitulation of Learners' Scores}

\begin{tabular}{cccc}
\hline Subjects & Perception & Satisfaction & Learning Outcomes \\
\hline A & 89.286 & 87.5 & 70.0 \\
B & 94.643 & 90.0 & 65.0 \\
C & 94.643 & 92.5 & 85.0 \\
D & 91.071 & 85.0 & 60.0 \\
E & 94.643 & 92.5 & 75.0 \\
F & 94.643 & 90.0 & 77.5 \\
G & 85.714 & 80.0 & 65.0 \\
H & 94.643 & 92.5 & 86.0 \\
I & 82.143 & 77.5 & 60.0 \\
J & 92.857 & 95.0 & 72.5 \\
K & 89.286 & 87.5 & 75.0 \\
L & 80.357 & 77.5 & 67.0 \\
M & 85.714 & 85.0 & 65.0 \\
N & 89.286 & 92.5 & 75.0 \\
O & 98.214 & 97.5 & 75.0 \\
P & 85.714 & 85.0 & 70.0 \\
Q & 82.143 & 90.0 & 75.0 \\
R & 92.857 & 95.0 & 77.0 \\
S & 92.857 & 95.0 & 75.0 \\
T & 92.857 & 95.0 & 77.5 \\
U & 92.857 & 100 & 72.5 \\
\hline
\end{tabular}

